\title{
Effect of Cow Dung Vermicompost Rate on Growth of Snap Bean (Phaseolus vulgaris L.) Varieties at Jimma, South Western Ethiopia
}

\author{
Wendimu Melese ${ }^{1, *}$, Gezehagn Berecha ${ }^{2}$, Deribew Belew ${ }^{2}$ \\ ${ }^{1}$ Department of Horticulture, College of Agriculture and Natural Resources, Dilla University, Dilla, Ethiopia \\ ${ }^{2}$ Department of Horticulture and Plant Science, College of Agriculture and Veterinary Medicine, JimmaUniversity, Jimma, Ethiopia \\ Email address: \\ wendem08@gmail.com (W. Melese), gezish76@gmail.com (G. Berecha), dbelew2002@yahoo.com (D. Belew) \\ ${ }^{*}$ Corresponding author
}

To cite this article:

Wendimu Melese, Gezehagn Berecha, Deribew Belew. Effect of Cow Dung Vermicompost Rate on Growth of Snap Bean (Phaseolus vulgaris L.) Varieties at Jimma, South Western Ethiopia. International Journal of Applied Agricultural Sciences.

Vol. 6, No. 3, 2020, pp. 26-34. doi: 10.11648/j.ijaas.20200603.11

Received: March 7, 2020; Accepted: April 8, 2020; Published: May 28, 2020

\begin{abstract}
The objective of this experiment was to determine the response of snap bean varieties to different rates of cow dung vermicompost and their interaction effects. A $3 \times 4$ factorial experiment arranged in a randomized complete block design (RCBD) with three replications was carried out under Lath house condition. Factor one consisted three varieties of snap bean (Plati, Faraday and BC4.4), while Factor two consisted four rates of cow dung vermicompost application rate and 1 recommended rate of NPS (R5). The results revealed that, the main effects of vermicompost rates and snap bean variety showed significant difference $(\mathrm{P} \leq 0.05)$ for all growth parameters studied except for total leaf chlorophyll content. Accordingly, the interaction effect of vermicompost rate and variety were significant for Plant dry weight. Therefore, taking the findings of the present study in to consideration, it may be tentatively concluded that, the farmers at the Jimma may apply the combination of 45t/ha cow dung vermicompost and Variety BC4.4 would help to improve the growth of Snap bean. However, repeating the same study across season and location at field condition would help to draw sound conclusion and recommendations. Hence, future studies should look in to these factors to develop cow dung vermicompost fertilizer and snap bean varieties recommendation for optimum growth of snap bean in Jimma area.
\end{abstract}

Keywords: Vermicompost, Snap Bean, Growth, Variety

\section{Introduction}

Snapbean (Phaseolus vulgaris L.) is dicotyledonous plant, and member of the family, Fabaceae. It is a legume crop grown worldwide [1]. There are more than 130 varieties of snap bean in the world [2]. It is also often called as green beans, because, years ago, fibrous string (vascular tissue) run along the seam of the bean pod and was noticeable when the beans are snapped [3]. The snapping noise is the reason for its other nick name "Snap" bean. It has been among the most important and highly prioritized crops as a means of foreign currency earning in Ethiopia [4].

The total worldwide cultivated area of green beans is $1,527,613$ hectares, producing $21,720,588$ tons [5]. China is the world's leading producer of green beans, with a total cultivated area of 635,385 hectares and a production of $17,031,702$ tons [5]. About $50 \%$ and $30 \%$ of world production comes from Asia and Europe, respectively.

In Ethiopia, there is no exact information as to when snap bean was first introduced; however, some literatures indicated that, the crop is cultivated in different major growing areas of the country in the early 1970 century with the purpose of exporting to different market destinations [6]. It covered an area of 1749 ha in 2016 production year with total production of 7187 tons, which was equivalent to 4.1 tons/ha [7]. The area and production of snap bean in Ethiopia between the years 2003 and 2013, was increased by $76.5 \%$ and $77.1 \%$, respectively [8].

Vermicompost is an eco-friendly, cost effective and ecologically sound bio-fertilizer [9]. Therefore, it is a simple 
biotechnological process of composting [10]. A widely used premium organic fertilizer is the by-product of symbiotic interactions between earthworms and microorganisms living within them [11]. Use of vermicompost is effective for improving soil aggregation, structure, aeration and fertility (physical properties); contains most of the nutrients in plant available form such as nitrates, phosphates, exchangeable calcium and soluble potassium; increases beneficial microbial population diversity and activity; improves soil moisture holding capacity; contains vitamins, enzymes and hormones; and accelerates the population and activity of earthworms [12].

\section{Results and Discussion}

\subsection{Plant Height (cm)}

Plant height was highly significantly $(\mathrm{P}<0.001)$ affected by main effects of vermicompost application rate and snap bean variety. Snap bean plants that received $45 \mathrm{t} /$ ha vermicompost,

$\mathrm{CV}(\%)=11.6373$ and LSD $(0.05)=4.5586$

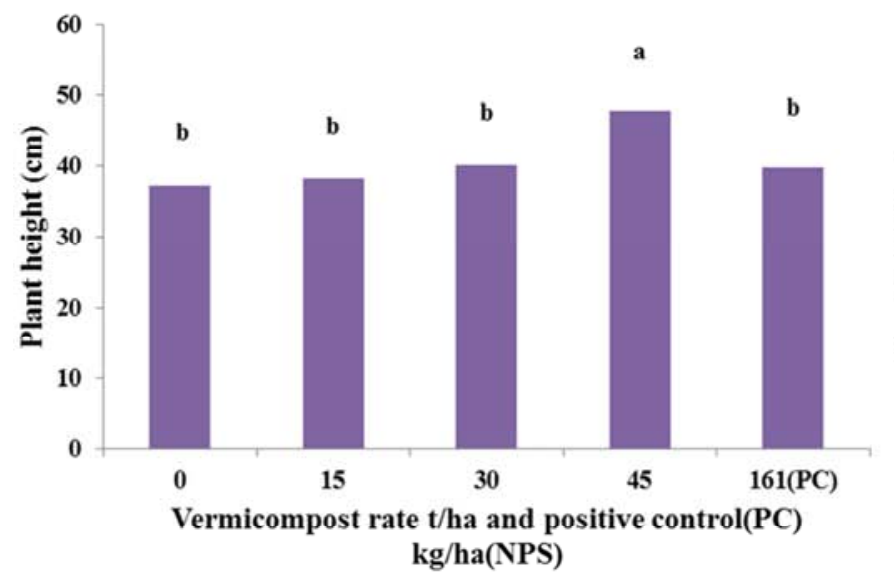

A recorded with significantly the highest plant height (47.809 $\mathrm{cm})$, (Figure 1A). While the other treatments $(0,15$ and 30 t/ha vermicompost, and $161 \mathrm{~kg} / \mathrm{ha}$ NPS (positive control) were not statistically different from one another. Increase in plant height could be due to improvement in the physcochemical properties of soil, increase in growth hormones, increase in enzymatic activity, increase in microbial population and activity and easy availability of macro- and micronutrients in relation to humic acid production by application of vermicompost. The result is in line with those reported by various authors [13-19], observed that significantly the highest plant height as a result of vermicompost application (75\%).

The highest plant height $(45.42 \mathrm{~cm})$ was recorded by the snap bean variety $\mathrm{BC} 4.4$, followed byvarietyPlati $(39.66 \mathrm{~cm})$ and variety Faraday $(36.62 \mathrm{~cm})$ both of which were not statistically different from one another (Figure 1B). This couldbe due to, genotypic difference among varieties.

\section{$C V(\%)=11.6373$ and LSD $(0.05)=3.5311$}

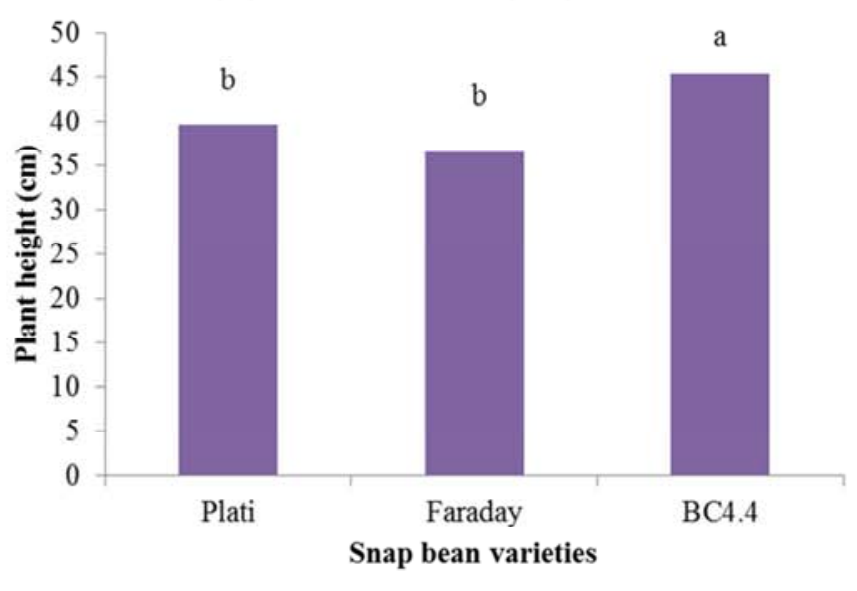

$\mathrm{B}$

Figure 1. Effect of vermicompost rate (A) and variety (B) on plant height of snap bean.

\subsection{Number of Primary Branches per Plant}

Vermicompost rate was highly significantly $(\mathrm{P}<0.001)$ affected number of primary branches per plant. The highest number of primary branches (5.22) was obtained from the snap bean plants treated with $45 \mathrm{t} /$ ha vermicompost rate, followed by $30 \mathrm{t} / \mathrm{ha}$. Whereas the least number of primary branches was obtained from snap bean plants treated with $15 \mathrm{t} / \mathrm{ha}$ vermicompost and $161 \mathrm{~kg} / \mathrm{ha}$ NPS as well as the control. According to [9], 25\% rate of mineral nutrients + vermicompost $3.75 \mathrm{t} / \mathrm{ha}$ in combination gave better results as compared to single application. However, vermicompost at a rate of $45 \mathrm{t} / \mathrm{ha}$ and $30 \mathrm{t} / \mathrm{ha}$ applied alone ever seen with increased number of primary branches probably due to vermicompost as this activates plant hormones that are responsible to promote number of branches. The current study result is in line with the study result of [9] who declared that, the increased amount of humus in soil through application of vermicompost and decomposition of organic mulches by earthworms would certainly help favorable change in physical, chemical and biological properties of soil, and in enhancing the water-holding capacity increased plant growth.

In the current study, variety also affected number of primary branches per plant $(\mathrm{P}<0.05)$. The analysis of variance indicated that, variety Faraday found to be superior by producing 4.4 primary branches per plant, followed by BC4.4 (4.15) and Plati (3.512). However, statistically there was no difference among the first two varieties (Figure $2 \mathrm{~B}$ ). This is probably due to snap bean variety Faraday is more responsive to the vermicompost rate it received. This result is in line with the result of [20], who reported that, variety highly significantly affected the number of primary branches. 
$\operatorname{CV}(\%)=12.49$ and LSD $(0.05)=0.48$

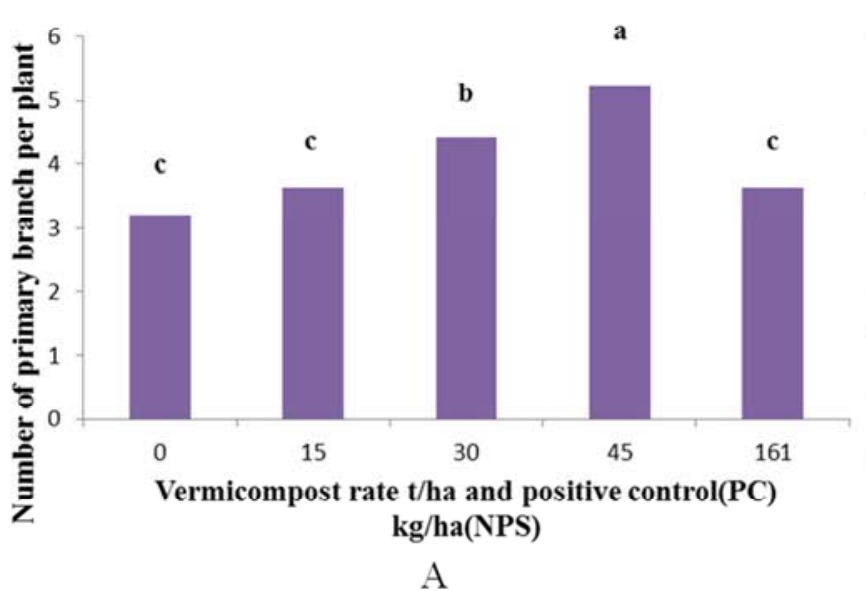

CV $(\%)=12.49$ and LSD $(0.05)=0.37$

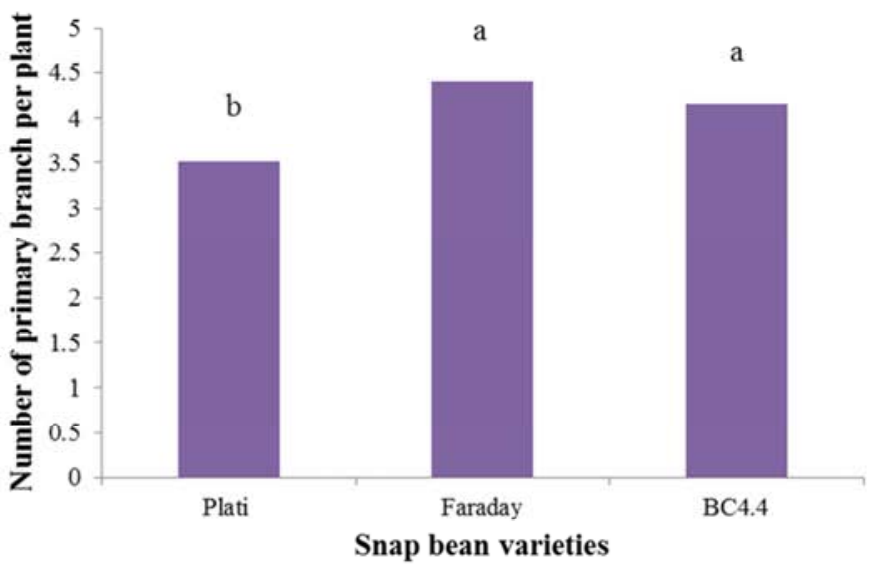

B

Figure 2. Effect of vermicompost rate (A) and varietal difference (B) of snap bean on number of primary branches per plant.

\subsection{Leaf Area $\left(\mathrm{cm}^{2}\right)$}

Leaf area was highly significantly $(\mathrm{P}<0.001)$ affected by main effects of vermicompost application rate and snap bean variety. Snap bean plants treated with 45 and $30 \mathrm{t} / \mathrm{ha}$ vermicompost, recorded the highest leaf area (48.717and $45.68 \mathrm{~cm}$ ), followed by snap bean plants treated with $15 \mathrm{t} / \mathrm{ha}$ vermicompost and $161 \mathrm{~kg} / \mathrm{ha}$ as well as control (Figure $3 \mathrm{~A}$ ). Increase in leaf area of snap bean plants which received 45 and 30t/ha vermicompost could be because vermicompost improves physco-chemical properties of soil which used in the experiment. According to [21], growth of snap bean plants was increased because of high porosity, aeration, drainage, and water-holding capacity of the soil is improved due to vermicompost application. This result is in line with the result of [22], who reported tha, increased leaf area due to application of vermicompost.

Variety was significantly $(\mathrm{P}<0.001)$ affected leaf area. The highest leaf area $\left(49.103 \mathrm{~cm}^{2}\right)$, was recorded from variety BC4.4, followed by Plati (39.583) and Faraday (39.14), both of which were not statistically different from one another (Figure 3B). Variety BC4.4 has a better performance to use nutrient which probably is obtained due to vermicompost application which may also be associated with Nitrogen nutrient production inside soil [21]. As far as sufficient $\mathrm{N}$ is found in the soil, plant vegetative growth expected to be trigged and give a larger leaf size.

\section{$\operatorname{CV}(\%)=12.17$ and LSD $(0.05)=3.87$}

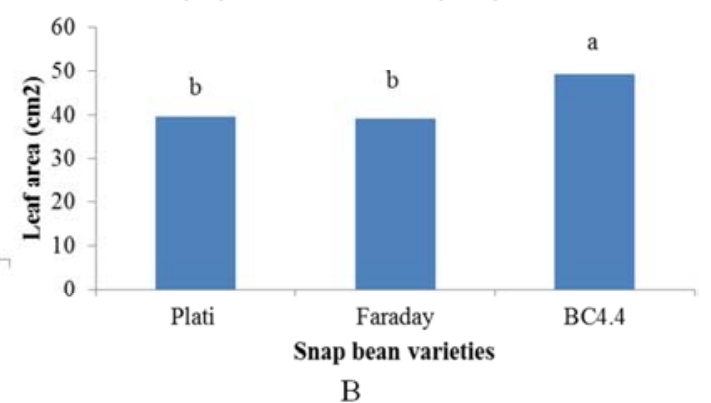

B

Figure 3. Effect of vermicompost rate (A) and varietal difference (B) of snap bean on leaf area.

\subsection{Number of Leaf Per Plant}

Number of leaf per plant was significantly $(\mathrm{P}<0.05)$ affected by main effects of vermicompost application rate and snap bean variety. From snap bean plants which treated with vermicompost at a rate of $45 \mathrm{t} / \mathrm{ha}$, recorded with significantly the highest number of leaves (38.733), whereas treatments $30,15 \mathrm{t} / \mathrm{ha}$ vermicompost and $161 \mathrm{~kg} / \mathrm{ha}$ NPS as well as control, remained statistically similar (Figure4A). The highest number of leaves recorded could be due to the improved physco-chemical properties and increased nutrient in the media as well as increased growth hormones such as Indole acetic acid, gibberellins and cytokinins by microorganisms in the root zone of soil after vermicompost application. According to [23], snap bean is the most responsive plant to vermicompost application out of leguminous crops. The current result is consistent with the result of $[24,19]$, who reported that, the highest number of leaves per plant from plants grown with the application of vermicompost.

Varietywas also significantly $(\mathrm{P}<0.05)$ affected number of leaves per plant. The highest number of leaves was obtained from variety BC4.4 (37.69), followed by Faraday and Plati 
varieties, which however, were not statistically different from one another (Figure 4B). The highest number of leaves obtained from variety $\mathrm{BC} 4.4$ probably is related to the snap bean nutrient use efficiency. According to [25], variety highly

CV(\%)=10.18 and LSD $(0.05)=3.41$

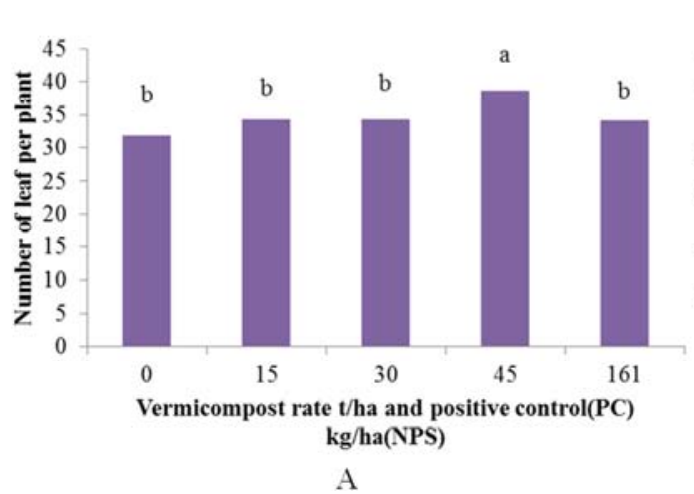

affects $\mathrm{N}$ use efficiency in snap bean. The result is also in conformity with the result of $[26,20]$, who observed that, differences in vegetative growth of cultivars mainly due to their genotype variation.

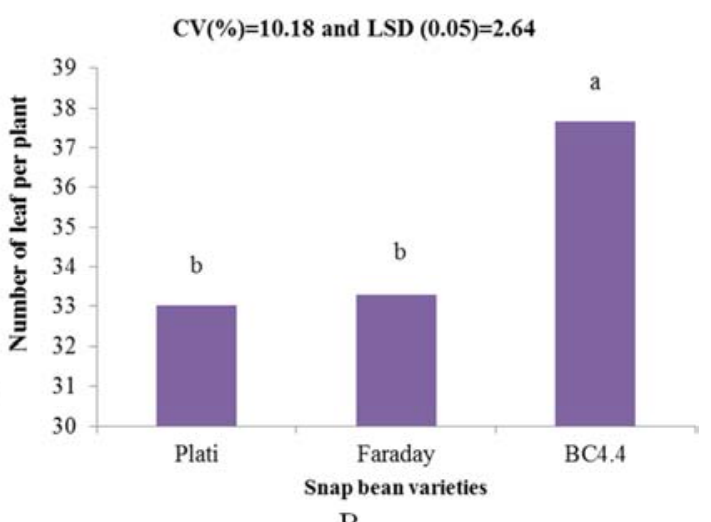

B

Figure 4. Effect of vermicompost rate (A) and snap bean varietal difference (B) on number of leaf per plant.

\subsection{Total Leaf Chlorophyll Content $\left(\mu \mathrm{mol} / \mathrm{cm}^{2}\right)$}

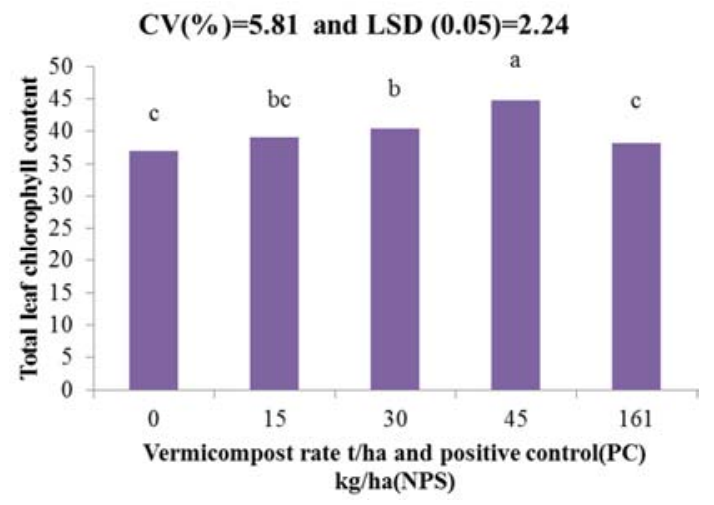

Figure 5. Effect of vermicompost rate on snap bean total leaf chlorophyll content per plant.

Total leaf chlorophyll content is highly significantly $(\mathrm{P}<0.001)$ affected by vermicompost application rate. Snap bean plant which received $45 \mathrm{t} /$ ha vermicompost recorded the highest total leaf chlorophyll content $\left(44.772 \mu \mathrm{mol} / \mathrm{cm}^{2}\right)$, followed by $30 \mathrm{t} /$ ha vermicompost (Figure 5). This could probably be due to the concentration of nutrients in the growing soil which is directly associated with the rate of

$\operatorname{CV}(\%)=17.56$ and $\operatorname{LSD}(0.05)=0.54$

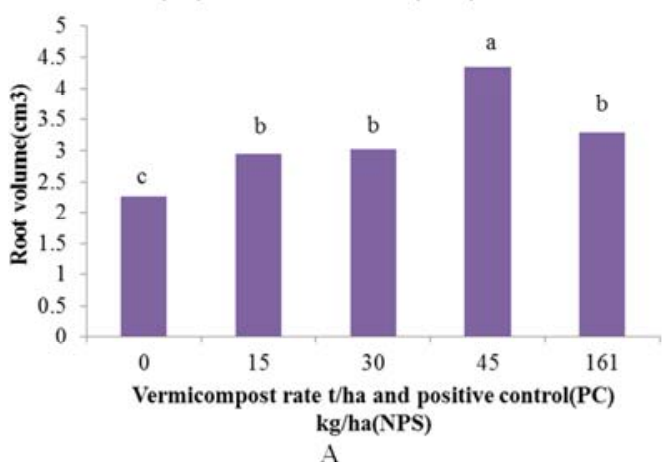

A vermicompost it received. [27], reported the highest chlorophyll content in Plectranthusambinoicus when diluted vermicomposting leachate was used as a nutrient solution. This result is in line with the result of [28], who reported that, the highest total chlorophyll content in response to high application rate ofvermicompost.

Total leaf chlorophyll content was not affected by snap bean varieties therefore, found to be non-significant.

\subsection{Root Volume $\left(\mathrm{cm}^{3}\right)$}

Vermicompost application rate was significantly $(\mathrm{P}<0.05)$ affected root volume. The highest root volume $\left(4.35 \mathrm{~cm}^{3}\right)$ was recorded from snap bean plants treated with $45 \mathrm{t} / \mathrm{ha}$ of vermicompost, whereas the least root volume was obtained from the control treatment (Figure 6A). This probably is because vermicompost improves soil structure and porosity which in turn favors the root size increase in the media. Consequently, vermicompost also adds some beneficial microorganisms and the egg of earth worms that are highly beneficial in the opening of ways for the movement of air in the soil [23]. Result of the current study is in line with that reported by [29], who reported that, vermicomposts have been shown to improve plant growth significantly.

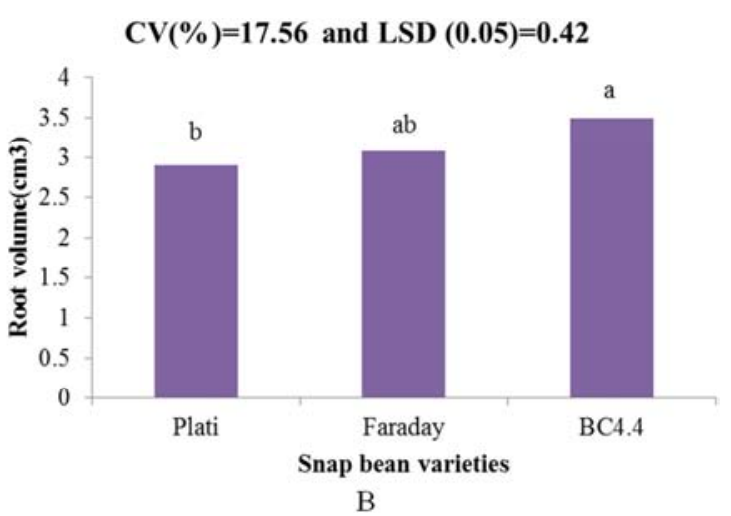

Figure 6. Effect of vermicompost rate (A) and variety (B) on root volume of snap bean. 
Root volume was highly significantly $(\mathrm{P}<0.001)$ affected by variety. The highest root volume $\left(3.5047 \mathrm{~cm}^{3}\right)$ was recorded from variety BC4.4 followed by variety Faraday $\left(3.0927 \mathrm{~cm}^{3}\right)$ and variety Plati $\left(2.9153 \mathrm{~cm}^{3}\right)$, both of which were not statistically different from one another (Figure6B). This study result is in line with the results of [30], who reported that, the root surface area is considerably extended due to nitrogen is found in the sources of nutrients. As it indicates variety $\mathrm{BC} 4.4$ could be better nutrient user as compared to others.

\subsection{Tap Root Length (cm)}

Tap root length was highly significantly $(\mathrm{P}<0.001)$ affected by the rate of vermicompost application. The highest tap root length $(41.143 \mathrm{~cm})$ was obtained from snap bean plants that treated with $45 \mathrm{t} /$ ha vermicompost, followed by $30 \mathrm{t} / \mathrm{ha}(36.293 \mathrm{~cm})$ and $15 \mathrm{t} / \mathrm{ha}(35.442 \mathrm{~cm})$, both of which were not statistically different from one another (Figure 7A). The least tap root length $(28.157 \mathrm{~cm})$ was obtained from the control which however was not statistically different from those which received $161 \mathrm{~kg} / \mathrm{ha}$

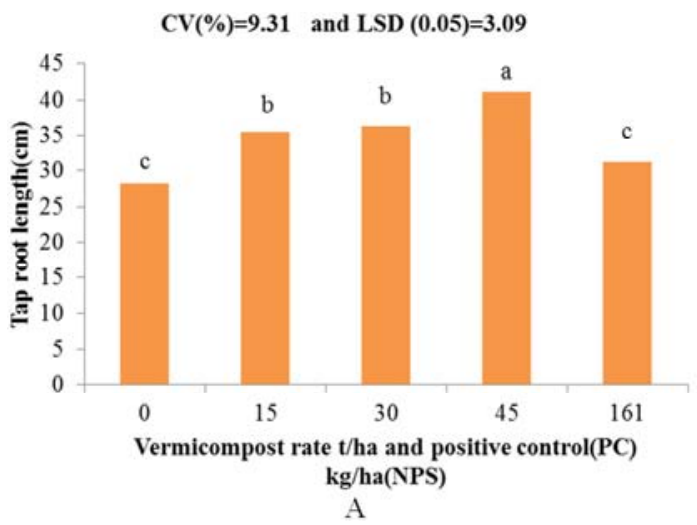

NPS. The 45t/ha vermicompost application increased tap root length of snap bean plants by $31.56 \%$. This probably is resulted due to increase in percent of organic matter, percent of total $\mathrm{N}$ and average $\mathrm{P}$ in the growing media after vermicompost application. According to [14], Vermicompost can enhance soil fertility physically, chemically and biologically. Vermicompost application increases macro pore space ranging from 50 to 500 $\mu \mathrm{m}$, resulting in improved air-water relationship in the soil which favorably affects tap root length [31]. This result is in line with the result ofwhere concluded that, nutrient content in plant and organic $\mathrm{C}$, available $\mathrm{N}, \mathrm{P}, \mathrm{K}$, and $\mathrm{CEC}$ in post-harvest soil were also significantly improved by the application of enriched vermicomposts [32].

Variety also highly significantly $(\mathrm{P}<0.001)$ affected Tap root length. The highest tap root length $(37.15 \mathrm{~cm})$ was obtained from variety $\mathrm{BC} 4.4$, which however was not significantly different from the variety Faraday $(35.95 \mathrm{~cm})$, while the least tap root length $(30.25 \mathrm{~cm})$ was recorded from variety Plati (Figure 7B).

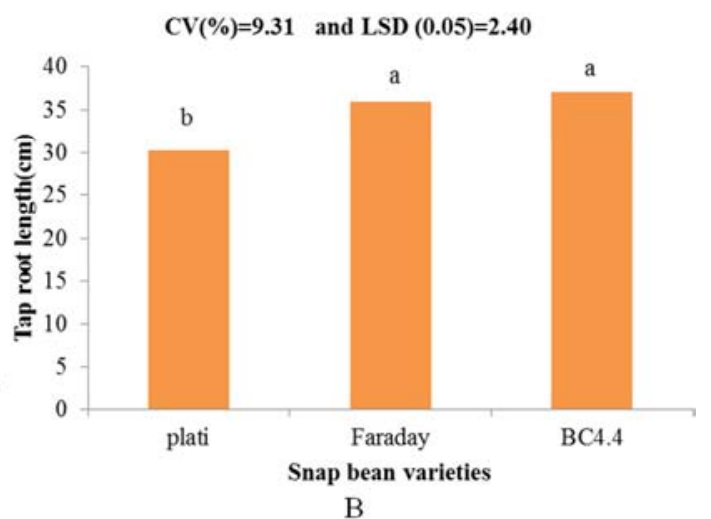

B

Figure 7. Effect of vermicompost rate (A) and variety (B) on tap root length of snap bean.

\subsection{Total Nodule Number}

Total nodule number is highly significantly $(\mathrm{P}<0.001)$ affected by vermicompost application rate. The highest nodule number (168.25) was recorded from snap bean plants treated with $45 \mathrm{t} / \mathrm{ha}$ vermicompost, however it was not significantly different from those treated with 30 and 15t/ha, whereas the least total number of nodule per plant is recorded from the control which however was not statistically different from those treated with $161 \mathrm{~kg} /$ ha NPS (Figure 8A). The snap bean plants treated with $45 \mathrm{t} / \mathrm{ha}$ vermicompost increased total nodule number by $29.57 \%$ as compared to the control. Theincrease in total nodule number could probably be due to increases in microorganisms which might be responsible in increasing nodule number as a result of vermicompost application [31]. Vermicompost also can be used as rhizobium inoculant since available $\mathrm{N}_{2}$ in vermicompost used as starter for symbiotic bacteria in the soil for $\mathrm{N}_{2}$ fixation.
This result is in line with those reported by various scholars $[33,34]$ in which nodule number of bean crops was affected by organic matter status of the soil.

Variety was significantly $(\mathrm{P}<0.001)$ affected number of nodule per plant. The highest number of nodule (167.93) was recorded by variety BC4.4, followed by Faraday (138.083) and Plati (137.7) varieties, both of which were not statistically different from one another (Figure 8B). Increased root volume and tap root length might have contributed in producing much secondary roots which in turn might have produced more nodule sites. In addition to this, due to the highest level vermicompost incorporated with the growing soil, the roots can easily penetrate throughout the growing media as vermicompost can improve the structure and texture of the soil. These results are in line with the study results of [23], who reported the highest number of nodules in vermicompost treated plantsthan in compost, control and $\mathrm{N}$ : $\mathrm{P}: \mathrm{K}$ treatments. 

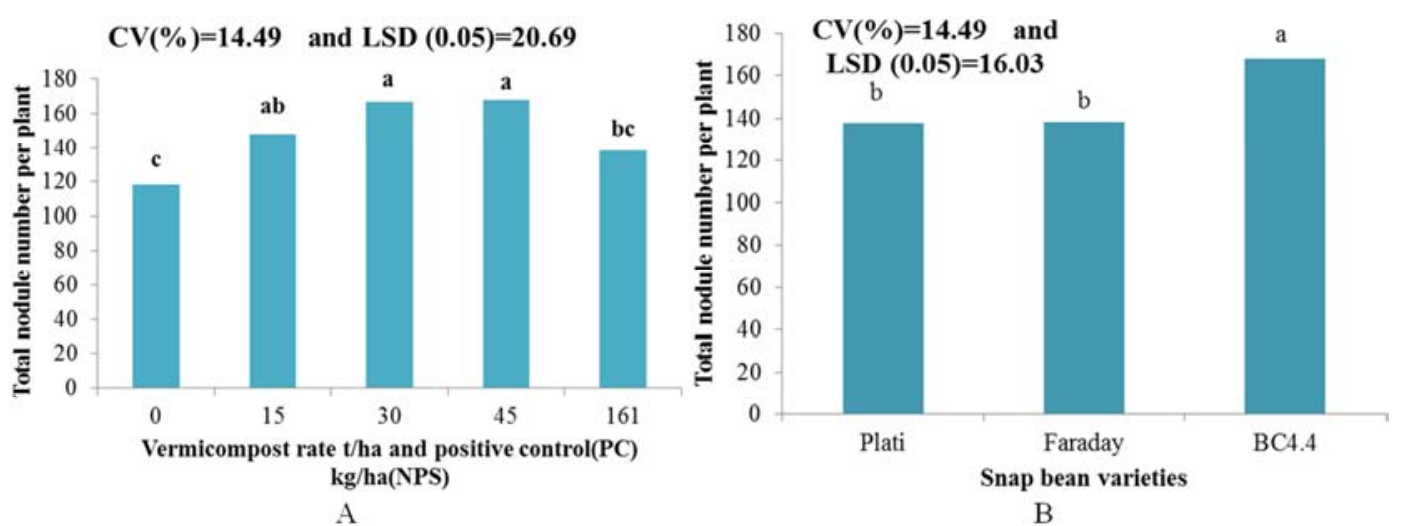

Figure 8. Effect of vermicompost rate (A) and variety $(B)$ on number of nodule per plant of snap bean.

\subsection{Nodule Weight per Plant (g)}

Nodule weight per plant was highly significantly $(\mathrm{P}<0.001)$ affected by vermicompost application rate. The highest nodule weight $(1.725 \mathrm{~g})$ per plant was recorded from snap bean plant treated with $45 \mathrm{t} / \mathrm{ha}$. However, statistically it was not different from snap bean plants $(1.65 \mathrm{~g})$ treated with $30 \mathrm{t} / \mathrm{ha}$ vermicompost, whereas the least nodule weight $(1.1867 \mathrm{~g})$, was recorded from the control (Figure 9A). Increase in nodule weight could probably be due to the increased number of nodule recorded which is associated with vermicompost

$\mathrm{CV}(\%)=12.99$ and LSD $(0.05)=0.18$

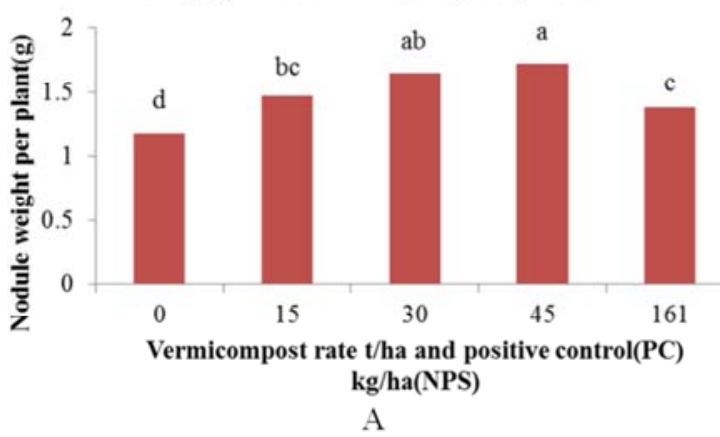

application. The result is in line with the result of [35], who reported that nodule weight is affected by number of nodule and the type of inoculant used for naturally found rhizobia.

Variety was highly significantly $(\mathrm{P}<0.001)$ affected nodule weight per plant. The highest weight $(1.68 \mathrm{~g})$ of nodule was recorded from snap bean variety $\mathrm{BC} 4.4$, followed by variety Plati $(1.4 \mathrm{~g})$, while the least nodule weight $(1.364 \mathrm{~g})$ was obtained from variety Faraday (Figure 9). This is may be because of variety $\mathrm{BC} 4.4$ recorded the highest tap root length, root volume and number of nodule, which in turn might have increased the weight of nodule.

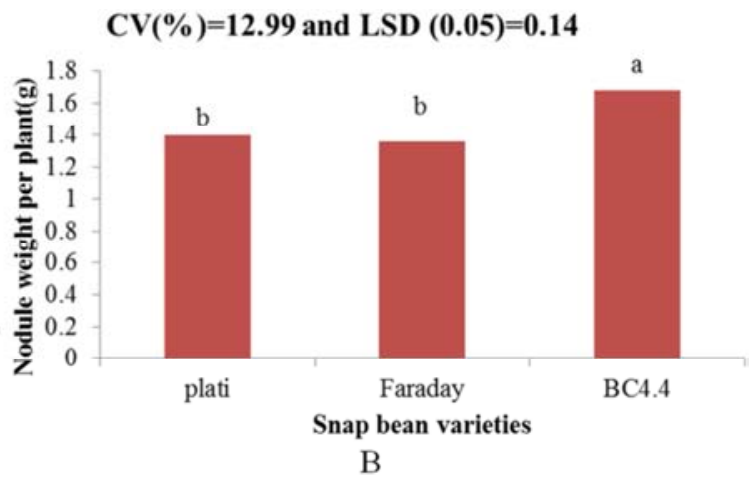

$\mathrm{B}$

Figure 9. Effect of vermicompost rate (A) and variety (B) on nodule weight per plant of snap bean.

\subsection{Effective Number of Nodule Per Plant}

Effective nodule number per plant was highly significantly $(\mathrm{P}<0.001)$ affected by vermicompost application rate. The highest number of effective nodules (155.56) was recorded from the snap bean plants that were treated with 45 t/ha vermicompost, which however, was not statistically different from those which received 30t/ha, whereas the lowest effective nodule number per plant (98.27) was recorded from the control (Figure 10A). Increase in effective nodule number could probably be due to improvement in the physco-chemical properties of soil, increase in enzymatic activity, increase in microbial population and activity and easy availability of macro- and micronutrients in relation to humic acid production by application of vermicompost. A typical symbiotic relationship is going on in effective nodule [36], so that the effective nodules are expected to produce $\mathrm{N}_{2}$. The study undertaken by [33], confirmed that, common bean can fix atmospheric $\mathrm{N}$ and incorporate it in to the soil from $36 \mathrm{~kg}$ to $98 \mathrm{~kg}$ per hectare of land. These results are in harmony with the result of [34], where he concluded that, the number of effective nodules in bush bean, winged bean and yard long bean was also observed to be significantly higher in the vermicompost treated plants.

Varietal differences among snap bean plants, obtained to be significantly affected effective nodule number per plant at $(\mathrm{P}<0.001)$. In this case, the highest effective nodule number (155.58) was recorded from variety BC4.4 followed by variety Faraday (126.45) and variety Plati (122.29) both of which were not statistically different from one another (Figure 10B). Therefore, variety $\mathrm{BC} 4.4$ is found to be a superior over other varieties, probably be due to the genotype difference and Rhizobium strains found in nodule. It also indicated that, this variety is producing more $\mathrm{N}_{2}$ for the growth and development of the crop which is also directly determining factor to increase or decrease the yield of the 
crop. This study is in line with the result of [37], who concluded that, in beans, significantly different effects

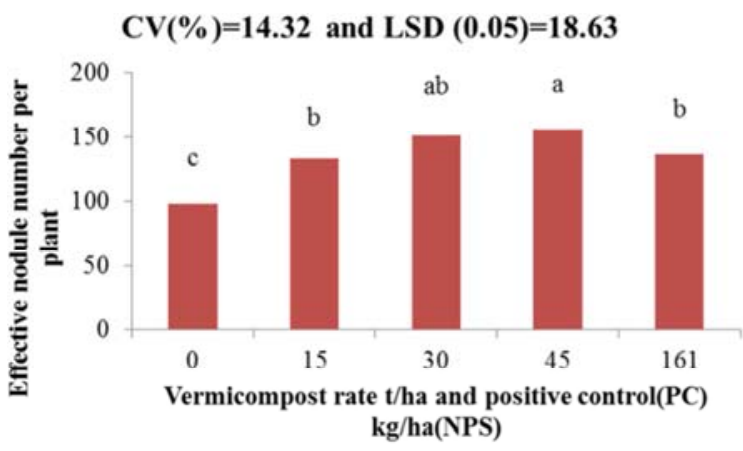

A between cultivars and Rhizobium strains in plant growth.

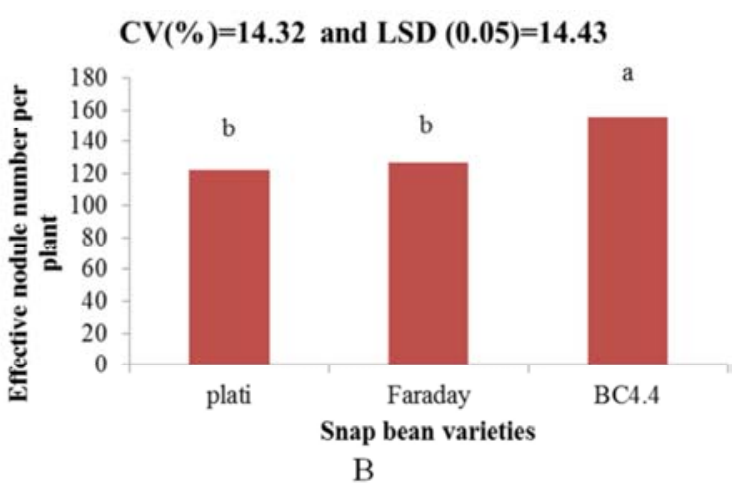

Figure 10. Effect of Vermicompost rate (A) and varietal difference among snap bean (B) on effective nodule number per plant.

\subsection{Plant Biomass (g)}

Plant biomass was affected highly significantly $(\mathrm{P}<0.001)$ by vermicompost application rate. The highest plant biomass (36.5g) was recorded from snap bean plant which received $161 \mathrm{~kg} / \mathrm{ha}$ NPS rate (positive control), while the least plant biomass $(27.167 \mathrm{~g})$ was recorded from the control (Figure 11A). This however was not statistically different from those which treated with 45,30 and 15t/ha vermicompost. The highest plant biomass (expressed in terms of weight of the root and above ground shoot) recorded from plants treated with $161 \mathrm{~kg} /$ ha NPS could probably be due to lower amount of nutrients are used by the plant to produce the pod, while the remaining nutrients contributed for the highest plant biomass. According to [38], the amount of $\mathrm{N}$ applied had a

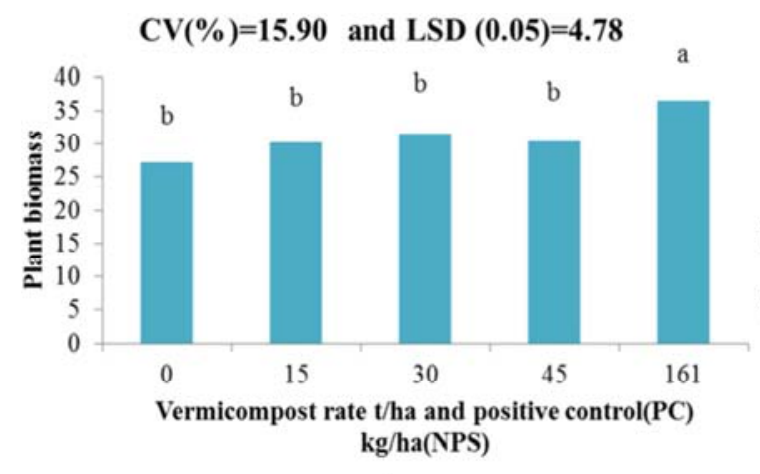

A small, non-significant influence on yield, but increased the vegetative growth. The weight of the vegetative plant partsaremostly related with the responsiveness of the crops to NPS fertilizer that could be better than that of vermicompost. These results are in line with the findings of [39], who reported a significant amount of $\mathrm{N}$ accumulated in biomass part, but with less effect on yield.

Varietal differences highly significantly $(\mathrm{P}<0.01)$ affected plant biomass. The highest plant biomass (37.183g) was obtained from variety BC4.4, followed by variety Plati $(29.127 \mathrm{~g})$ and variety Faraday $(27.117 \mathrm{~g})$ (Figure 11B). This is probably due to the genotype difference between varieties used in the experiment. This result is in line with the results of [25], who reported that, variety highly affects $\mathrm{N}$ use efficiency in snap bean due to varietaldifference.

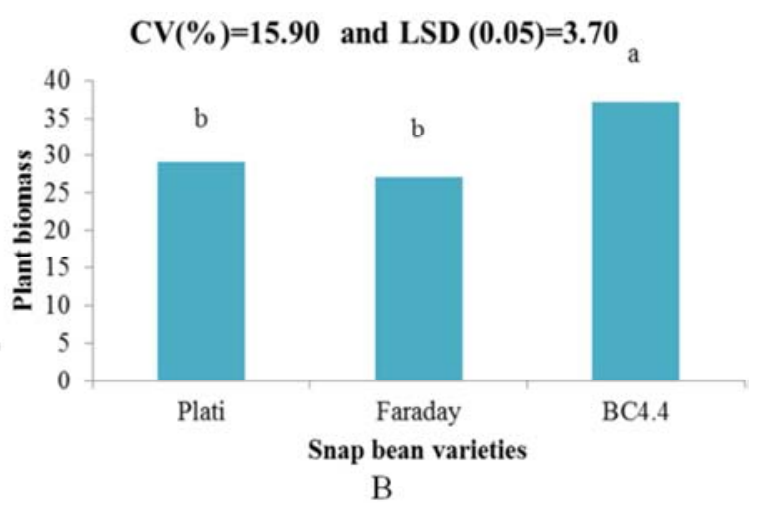

Figure 11. Effect of vermicompost rate (A) and snap bean variety (B) on plant biomass.

\subsection{Plant Dry Weight}

Results shown in Table 1 indicated that, there were a significant $(\mathrm{P}<0.05)$ interaction effect of vermicompost rate and variety on plant dry weight of snap bean. The highest plant dry weight $(10 \mathrm{~g})$ was recorded from the combination of variety $\mathrm{BC} 4.4$ and $45 \mathrm{t} / \mathrm{ha}$ vermicompost rate. However, it was not statistically different from the combination of variety Plati with $15 \mathrm{t} / \mathrm{ha}$ vermicompost rate, variety $\mathrm{BC} 4.4$ with $161 \mathrm{~kg}$ NPS, Variety BC4.4 with 30t/ha vermicompost rate, Variety Plati with $161 \mathrm{~kg}$ NPS and Variety BC4.4 with
$15 \mathrm{t} /$ havermicompost rate. Whereas, the least plant dry weight (6.33) was recorded from the variety Faraday and 45t/ha vermicompost rate combination. The highest plant dry weight obtained from the combination of variety BC4.4 and $45 \mathrm{t} / \mathrm{ha}$ vermicompost application rate, could probably be because this varietyis more efficient than others in utilizing the highest vermicompost rate it received. [40], who reported that, the difference in the performance of the cultivars due to their genetic nature. This result is in line with the results of [41], who reported that, effective results in terms of plant dry weight as a result of application of organic fertilizer. 
Table 1. Interaction effect of Snap bean variety and Vermicompost rate on plant dry weight.

\begin{tabular}{lll}
\hline Factors & & Plant dry weight \\
\hline Variety & Rate of VC & \\
Plati & 0 & $6.5 \mathrm{de}$ \\
& $15 \mathrm{t} / \mathrm{ha}$ & $9.08 \mathrm{ab}$ \\
& $30 \mathrm{t} / \mathrm{ha}$ & $7.83 \mathrm{bcde}$ \\
& $45 \mathrm{t} / \mathrm{ha}$ & $6.33 \mathrm{e}$ \\
& $161 \mathrm{~kg} / \mathrm{ha} \mathrm{NPS}$ & $8.75 \mathrm{abc}$ \\
Faraday & 0 & $6.58 \mathrm{de}$ \\
& $15 \mathrm{t} / \mathrm{ha}$ & $6.5 \mathrm{de}$ \\
& $30 \mathrm{t} / \mathrm{ha}$ & $7 \mathrm{cde}$ \\
& $45 \mathrm{t} / \mathrm{ha}$ & $6.8 \mathrm{de}$ \\
$\mathrm{BC} 4.4$ & $161 \mathrm{~kg} / \mathrm{ha} \mathrm{NPS}$ & $7.58 \mathrm{bcde}$ \\
& 0 & $7.5 \mathrm{bcde}$ \\
& $15 \mathrm{t} / \mathrm{ha}$ & $8.25 \mathrm{abcd}$ \\
& $30 \mathrm{t} / \mathrm{ha}$ & $8.83 \mathrm{abc}$ \\
LSD $(0.05)$ & $45 \mathrm{t} / \mathrm{ha}$ & $10 \mathrm{a}$ \\
CV $(\%)$ & $161 \mathrm{~kg} / \mathrm{ha} \mathrm{NPS}$ & $8.92 \mathrm{ab}$ \\
& & 1.8471 \\
\hline
\end{tabular}

Means followed by the same letter within a column in a treatment are not significantly different at $\mathrm{P}=0.05$. VC=Vermicompost, $\mathrm{NPS}=$ Nitrogen Phosphorus and Sulphur, LSD=Least significant difference, $\mathrm{CV}=$ Coefficient of Variance.

\section{Conclusion}

The findings of the studies revealed that, different rates of vermicompost significantly influenced the growth, attributes of snap bean. Application of $45 \mathrm{t} / \mathrm{ha}$ vermicompost rate produced the highest value for plant height, number of primary branch per plant, leaf area, number of leaf per plant, total leaf chlorophyll content, root volume, tap root length, total nodule number, nodule weight and effective number of nodule. The highest plant biomass was obtained from the positive control treatment $(161 \mathrm{~kg} / \mathrm{ha})$ NPS. Whereas, the interaction of variety $\mathrm{BC} 4.4$ and $45 \mathrm{t} / \mathrm{ha}$ vermicompost recorded with highest plant dry weight. Of varieties used in this study, variety $\mathrm{BC} 4.4$ recorded the highest value on plant height, leaf area, number of leaf per plant, root volume, tap root length, total nodule number, nodule weight and effective nodule number. Whereas, variety Faraday was also recorded with highest number of primary branch per plant which was also at par with variety BC4.4.

\section{Future Line of Works}

1. Similar experiment is suggusted to be carried out at field condition during the main rainy season involving different vermicompost produced from different feed stalks and varieties.

2. Assessment of effect of integrated use of vermicompost and some inorganic fertilizer such as NPS, NPSB etc, on growth of snap bean.

\section{Acknowledgements}

Above all, Glory to the Almighty God for everything happened in our life and helped us from the beginning to the end of this work. Also we would like to thank Jimma University College of Agriculture and Veterinary Medicine Managements and all the staff.

\section{References}

[1] H. J. S. Finch, G. P. F. Lane, in Lockhart \& Wiseman's, 2014, crop husbandry including grassland, science direct journals and book, (9) 5: 396-430.

[2] Megan Ware, 2018, everything you need to know about green beans, a newsletter, retrieved from, https://www.medicalnewstoday.com/articles.

[3] Kerr, Lynn B., 1971, The Flat Pod Rogue in Snap Beans (Phaseolus vulgaris L.), All Graduate Theses and Dissertations, 67: 5-1971.

[4] Gezahegne A, Dawit A 2006, food and forage legumes of Ethiopia; progress and prospectproceedings of the work shop on food and forage legume, 13 (7): 22- 26.

[5] FAO stat, 2017, Green Bean World Statistics. Major food and agricultural commodities producers - Countries by commodity. Available online: www.faostat.fao.org.

[6] Yosef Alemu, Sintayew Alamirew and Lemma Desalegn, 2013, Genetic variability in snap bean (phaseolus vulgaris) in central rift valley of Ethiopia, international journal of plant breeding and genetics, 7 (2): 124-131.

[7] FAO 2018, Production year book, Food and Agriculture Organization Statistical Database. Available at www.faostat.org.

[8] Damiany Pádua Oliveira, Sindynara Ferreira, Bruno Lima Soares, Paulo AdemarAvelar Ferreira, Augusto Ramalho de Morais, Fatima Maria de Souza Moreira, Messias José Bastos de Andrade, 2017, rhizobium strains selected from the Amazon region increase the yield of snap bean genotypes in protected cultivation, (10) 5, Pp 1678-1699.

[9] Arora V. K., Singh C. B., Sidhu A. S., Thind S. S. 2011. Irrigation, tillage and mulching effects on soybean yield and water productivity in relation to soil texture, Agricultural Water Management 18 (6): 563-568.

[10] Nagavallemma KP, Wani SP, Stephane Lacroix, Padmaja VV, Vineela C, Babu Rao M and Sahrawat KL, 2006, recycling wastes into valuable organic fertilizer, Andhra Pradesh, India, International Crops Research Institute for the Semi-Arid Tropics, 71: 20.

[11] Hong Zhang, Swee Ngin Tan, Chee How Teo, Yan Ru Yew, Liya Ge, Xin Chen and Jean Wan Hong Yong, 2015, analysis of phytohormones in vermicompost using a novel combinative sample preparation strategy of ultrasound-assisted extraction and solid-phase extraction coupled with liquid chromatography-tandem mass spectrometry, Talanta, http://dx.doi.org/10.1016/j.talanta.

[12] Aggelides S. M., and Londra P. A. 1999, effect of compost produced from town waste and sewage sludge on the physical properties of a loamy and a clay soil. Bioresource Technology, 71:253-259.

[13] Albiach R., Canet R., Pomares F., Ingelmo F. 2000, microbial biomass content and enzymatic activities after application of organic amendments to a horticultural soil, Bio-resource Technology, 75: 43-48. 
[14] Norman Q. Arancon and Clive A. Edwards, 2005, effects of vermicomposts on plant growth, Soil Ecology Laboratory, The Ohio State University, Columbus, OH 43210 USA, (8) 3: 1-25.

[15] Arancon N. Q, Edwards C. A., Bierman P. 2006, influences of Vermicomposts on field strawberries: Part 2, effects on soil microbial and chemical properties, Bio-resource Technology, 97: 831-840.

[16] Prabha K. P, Loretta Y. L., Usha R. K., 2007, an experimental study of vermin-bio-waste composting for agricultural soil improvement, bio-resource Technology, 4 (1): 1672-1681.

[17] Rasool Azarmi, Parviz Sharifi Ziveh and Mohammad Reza Satari, 2008, effect of Vermicompost on Growth, Yield and Nutrition Status of Tomato (Lycopersicum esculentum), Pakistan Journal of Biological Sciences, 11 (14): 1797-1802.

[18] Ekinci M., Dursun A., 2009, effects of different mulch materials on plant growth, some quality parameters and yield in melon (Cucumis melo L.) cultivars in high altitude environmental condition, Pakistan Journal of Botany, 41 (4): 1891-1901.

[19] Eswaran. N and Mariselvi, S, 2016, Efficacy of Vermicompost on growth and yield parameters of Lycopersicum esculentum (Tomato), International Journal of Scientific and Research Publications, 6 (1): 2250-3153.

[20] Abdel-Mawgoud A. M. R, M El Desuki, Sr Salman and Sd Abou Hussein, (2005), performance of snap bean varieties as affected by different level of mineral fertilizer, journal of agronomy, 4 (3): 242-247.

[21] C. A. Edwards, I. Burrows and C. A. Edwards, E. F. Neuhauser (Eds.), 1988, the potential of earthworm composts as plant growth media, in:, Earthworms in Waste and Environmental Management, SPB Academic Publ. Co., the Hague, Netherlands, (16) 8: 211-219.

[22] Hussien Mohammed Beshir, Bizuayehu Tesfaye, Rosalind Bueckertand Bunyamin Tar'an, 2015, African journal of agricultural research, 10 (32): 3157-3169.

[23] Singh NI, Chauhan JS, 2009, response of French bean (Phaseolus vulgaris L.) to organic manures and inorganic fertilizer on growth and yield parameters under irrigated condition, Nat Sci, 7 (5): Pp 1545-1740.

[24] K Chandrashekhar Reddy, K Malla Reddy - J. Res, 2005, different levels of vermicompost and nitrogen on growth and yield in onion (Allium cepa L.), (Raphanus sativus L.) cropping system, 16: 2224-3208.

[25] Matt Ruark, A. J. Bussan, Don Caine, Del Monte, Amanda Gevens, Amanda Raster, Yi Wang and Jaimie West, 2012, nitrogen management on snap beans, Midwest Food Processors Assoc, 19: 27-28.

[26] Tantawy AS, Abdel-Mawgoud AMR, Habib HAM, Hafez MM, 2009. Growth, productivity and pod quality responses of green bean plantsPhaseolus vulgaris to foliar application of nutrients and pollenextracts. Res. J. Agric. Biol. Sci., 5 (6): 1032-1038.

[27] S. Quaik, A. Embrandiri, P. F. Rupani, R. P. Singh and M. H. Ibrahim, 2001, effect of Vermi wash and Vermicomposting Leachate in Hydroponics Culture of Indian Borage (Plectranthus ambionicus) Plantlets. UMT 11th International Annual Symposium on Sustainability Science and Management, 3 (3): 210-214.
[28] Gianfranco Minotta and, Simone Pinzauti, 1996, effects of light and soil fertility on growth, leaf chlorophyll content and nutrient use efficiency of beech (Fagus syluatica L.) seedlings, Forest Ecology and Management, 14: 61-71.

[29] Su Lin Lim, Ta Yeong Wu, Pei Nie Lim, Katrina Pui Yee Shak, 2015, the use of vermicompost in organic farming, 95 (6): $1143-1156$

[30] Sattelmacher B, Kuene R, Malagamba P, Moreno U. 1990. Evaluation of tuber bearing Solanum species belonging to different ploidy levels for its yielding potential at low soil fertility. Plant and Soil, 129, 227-233.

[31] Marinari, S., Masciandaro, G., Ceccanti, B., and Grego, S., 2000, Influence of organic and mineral fertilizer on soil biological and mineral properties, Bioresource technonology 72: 9-17.

[32] K. Mahanta, D. K. Jha, D. J. Rajkhowa \& Manoj-Kumar (2012): Microbial enrichment of vermicompost prepared from different plant biomasses and their effect on rice (Oryza sativa L.) growth and soil fertility, Biological Agriculture \& Horticulture: An International Journal for Sustainable Production Systems, 28: 4, 241-250.

[33] Chris van Kessel and Christopher Hartley, 2000, Agricultural management of grain legumes: has it led to an increase in nitrogen fixation?, Field Crops Research, 7 (3): 165-181.

[34] Mohammad Aminul Islam, Amru Nasrulhaq Boyce, MdMotiorRahman, MohdSofianAzirunand Muhammad Aqeel Ashraf, 2016, effects of organic fertilizers on the growth and yield of bush bean, winged bean and yard long bean, Braz. Arch. Biol. Technol, 13 (7): 2-9.

[35] FAO/IAEA Division of Nuclear Techniques in Food and Agriculture, 1998, Improving yield and nitrogen fixation of grain legumes in the tropics and sub-tropics of Asia, Results of a co-ordinated research program, (18) 8: 1011-1289.

[36] Dušica Delić, Olivera Stajković, Nataša Rasulić, Djordje Kuzmanović, Dragana Jošić and Bogić Miličić, 2010, Nodulation and N2 Fixation Effectiveness of BradyrhizobiumStrains in Symbiosis with Adzuki Bean, Vignaangularis, 53 (2): 293-299.

[37] Ruy Raposeiras, Ivanildo Evódio Marriel, Maria Rita Scotti Muzzi, Edilson Paiva, Israel Alexandre Pereira Filho, Lilia Costa Carvalhais, Raul Vinícius Magalhães Passos, Patrícia Pereira Pintoand Nadja Maria Horta de Sá, 2006, Rhizobium strains competitiveness on bean nodulation in Cerrado soils, Pesq. agropec. bras., Brasília, 77: 439-447.

[38] Guangfeng Chen, Hongzhu Cao, Jun Liang, Wenqi Ma, Lufang Guo, Shuhua Zhang, Rongfeng Jiang, Hongyan Zhang, Keith W. T. Goulding and Fusuo Zhang, 2018, factors affecting nitrogen use efficiency and grain yield of summer maize on smallholder farms in the North China Plain, 7: 2-18.

[39] M. F. Hossain, 2006. Nutrients Removed in Harvested Portion of Crop by Continuous Corn Receiving Organic and Inorganic Fertilizers, Journal of Plant Sciences, 17: 264-272.

[40] Dalia Salman Khudair and Ali Hussein Jasim, 2019, effect of bio- and chemical fertilizers on green pods yield of some broad bean cultivars, plant archive, 7: 339-343.

[41] Chandan Singh Ahirwarand Azad Hussain, 2015, Effect of Vermicompost on Growth, Yield and Quality of Vegetable Crops, International Journal of Applied And Pure Science and Agriculture, (77) 5: 50-54. 